\title{
PENERAPAN MODEL PBL (PROBLEM BASED LEARNING) DALAM UPAYA \\ PENINGKATAN HASIL BELAJAR SISWA PADA KONSEP PENCEMARAN LINGKUNGAN DAN DAUR ULANG LIMBAH KELAS X3 MAN 1 MODEL KOTA BENGKULU.
}

\author{
RAHMI \\ Dosen Program Studi Pendidikan Biologi FKIP Universitas Riau Kepulauan
}

\begin{abstract}
ABSTRAK
Penelitian ini bertujuan untuk mengetahui hasil belajar biologi siswa dengan penerapan model PBL (problem based learning) dalam upaya peningkatan hasil belajar siswa pada konsep pencemaran lingkungan dan daur ulang limbah kelas X3 MAN 1 Model kota bengkulu. Jenis penelitian yang digunakan adalah penelitian tindakan kelas (PTK) yang dilaksanakan dalam 2 siklus, dimana tiap siklus ada 4 komponen, yaitu: 1) perencanaan (planning), 2) tindakan (acting), 3)pengamatan (observing), 4) refleksi (reflecting). Dari hasil penelitian diperoleh yaitu pada siklus 1 didapat rata-rata skor observasi akrivitas guru 24 yang termasuk dalam kategori cukup dan rata-rata aktivitas siswa 22,5 dengan kategori cukup. Sedangkan pada siklus II rata-rata skor aktivitas guru meningkat menjadi 31 kategori baik dan rata-rata skor siswa 33,5 juga kategori baik. Rata -rata hasil belajar siswa juga meningkat pada siklus 1 yaitu 61,61 dengan 15 orang siswa yang tuntas dari 31 siswa sedangkan pada siklus II rata-rata hasil belajar siswa 81,25 dengan 28 orang siswa yang tuntas dari 32 siswa. Analisis terhadap ketuntasan klasikal pada siklus 1 yaitu 51,61\% sedangkan pada siklus II ketuntasan belajar meningkat menjadi 87,5\%. Dari hasil analisis data tersebut menunjukkan bahwa proses pembeajaran biologi dengan menerapkan model PBL (probelm based learning) Dalam Upaya Peningkatan Hasil Belajar Siswa Pada Konsep Pencemaran Lingkungan Dan Daur Ulang Limbah sudah berjalan dengan baik dan dapat meningkatkan hasil belajar biologi siswa.
\end{abstract}

\section{Kata kunci: hasil belajar, aktivitas guru dan siswa , Problem Based Learning.}

\section{Pendahuluan}

Pendidikan adalah usaha sadar untuk menyiapkan peserta didik melalui kegiatan bimbingan, pengajaran, dan latihan bagi peranannya di masa yang akan datang. (UU RI No.2 Tahun 1989, Bab I, Pasal I). Pendidikan adalah suatu proses dalam rangka mempengaruhi peserta didik supaya mampu menyesuaikan diri sebaik mungkin dengan lingkungannya, dan dengan demikian akan menimbulkan perubahan pada dirinya (Hamalik, 2001: 2-3).

Pendidikan di sekolah terlalu menjejali otak anak dengan berbagai bahan ajar yang harus dihafal. Pendidikan tidak diarahkan untuk mengembangkan dan membangun karakter serta potensi yang dimiliki. Dengan kata lain, proses pendidikan kita tidak diarahkan membentuk manusia cerdas, memiliki kemampuan memecahkan masalah hidup, serta tidak diarahkan untuk membentuk manusia kreatif dan inovatif. Hal tersebut menyebabkan kurangnya aktivitas belajar anak dan masih rendahnya hasil belajar.

Kenyataannya dilapangan, berdasarkan hasil survey dan wawancara secara langsung dengan guru Biologi di MAN Model Kota Bengkulu, ternyata dalam pembelajaran Biologi kelas X.3, selama ini tidak menggunakan model dalam mengajar. Guru mengajar dengan berpusat pada guru, metode yang dilakukan dengan ceramah. Hasil wawancara dengan 
beberapa siswa kelas X.3 ternyata pada saat proses belajar terjadi ketidakjelasan bahan yang disampaikan. Sehingga hal ini menyebabkan berkurangnya aktivitas belajar anak, hingga akhirnya menyebabkan rendahnya hasil belajar anak.

Agar dalam proses pembelajaran, siswa mampu mengembangkan kemampuan berpikirnya, tidak hanya menerima informasi saja, serta dapat memberikan kesan kepada siswa bahwa biologi itu menyenangkan maka pada penelitian ini diterapkanlah Model PBL (Problem Based Learning). Tujuan penelitian ini adalah untuk mengetahui penerapan Model PBL (Problem Based Learning) dalam meningkatkan aktivitas guru dan siswa, dan hasil belajar siswa dalam pembelajaran biologi di Kelas X.3 MAN 1 Model Kota Bengkulu.

\section{Metodologi}

Jenis penelitian yang digunakan adalah Classroom Action Research (Penelitian Tindakan Kelas). Classroom Action Research (Penelitian Tindakan Kelas) adalah suatu perencanaan terhadap kegiatan belajar berupa sebuah tindakan yang sengaja dimunculkan dan terjadi dalam sebuah kelas secara bersama. (Arikunto, 2006: 3). Pada penelitian ini, akan dilakukan interaksi tindakan dalam pengajaran Biologi pada konsep pencemaran lingkungan dan daur ulang lingkungan melalui model PBL (Problem Based Learning).

\section{Hasil dan Pembahasan}

\subsection{Hasil Penelitian}

Dari penelitian yang sudah dilakukan dengan menggunakan model PBL (Problem Based Learning) dalam pembelajaran Biologi di kelas X3 MAN 1 Model Kota Bengkulu dilakukan dalam 2 siklus sebagai berikut:

\subsubsection{Refleksi Awal}

Sebelum dilaksanakan siklus I, terlebih dahulu diadakan tes awal. Berdasarkan hasil belajar siswa pada tes awal masih cukup rendah yaitu dengan rata-rata 4,45. Tes ini dimaksud untuk mengukur tingkat pemahaman materi siswa sebelum dimulainya materi pada pokok bahasan pencemaran lingkungan dan daur ulang limbah.

\subsubsection{Siklus I}

\section{a. Kegiatan awal/ rencana tindakan secara umum}

Siklus I dilaksanakan dalam waktu 2X45 menit dengan menerapkan model (Problem Based Learning) PBL. Kompetensi dasar yaitu menjelaskan keterkaitan manusia dengan masalah kerusakan, pencemaran lingkungan dan kelestarian lingkungan. Sebelum kegiatan pembelajaran dimulai terlebih dahulu dipersiapkan segala sesuatu yang dibutuhkan dalam pelaksanaan tindakan (Problem Based Learning) PBL.

\section{b. Tindakan I/ tahap pelaksanaan}

Tahapan ini dilanjutkan dengan pelajaran materi pencemaran lingkungan dan daur ulang limbah. Secara umum gambaran pelaksanaan pembelajaran dijelaskan. 


\section{c. Hasil Observsi siklus I}

Pada siklus I telah dilakukan observasi terhadap aktivitas guru dan siswa dalam proses pembelajaran dengan model Problem Based Learning.

1) Observasi siklus I

Adapun hasil analisa data dari aktvitas guru selama kegiatan pembelajaran pada pencemaran lingkungan dan daur ulang limbah dapat dilihat pada Tabel 4.1.

Tabel 4.1. Hasil Observasi Aktivitas Guru pada Siklus I

\begin{tabular}{|c|c|c|c|}
\hline \multicolumn{2}{|c|}{ Skor yang didapat } & Rata-rata skor & Kriteria \\
\hline Pengamat I & Pengamat II & & \\
\hline 25 & 23 & 24 & Cukup \\
\hline
\end{tabular}

Berdasarkan pengamatan yang dilakukan aktivitas guru selama proses pembelajaran pada siklus I mendapatkan skor 24 dalam kriteria cukup.

\section{2) Observasi Aktivitas siswa}

Hasil analisa data observasi dari aktivitas siswa dalam proses pembelajaran pada pencemaran lingkungan dan daur ulang limbah, dapat dilihat pada Tabel 4.2.

Tabel 4.2. Hasil Observasi Aktivitas Siswa pada Siklus I

\begin{tabular}{|c|c|c|c|}
\hline \multicolumn{2}{|c|}{ Skor yang didapat } & Rata-rata skor & \multirow{2}{*}{ Kriteria } \\
\cline { 1 - 2 } Pengamat I & Pengamat II & & \\
\hline 23 & 22 & 22,5 & Cukup \\
\hline
\end{tabular}

Berdasarkan pengamatan yang dilakukan pada aktivitas siswa selama proses pembelajaran siklus I terdapat kriteria cukup dengan rata-rata skor 22,5.

\section{d. Nilai akhir siswa}

Pada siklus I dilakukan proses pembelajaran biologi dengan pencemaran lingkungan dan daur ulang limbah dengan model (problem based learning) PBL. Penilaian yang digunakan berupa tes akhir. Nilai akhir ini untuk penilaian ketuntasan belajar siswa dan untuk melihat tercapai atau tidak ketuntasan belajar secara klasikal. Data nilai akhir siswa kelas X3 MAN 1 Model Kota Bengkulu pada siklus I dapat dilihat pada Tabel 4.3.

Tabel 4.3. Nilai akhir siswa pada siklus I

\begin{tabular}{|c|c|}
\hline Aspek penelitian & Siklus I \\
\hline Hasil belajar & 61,61 \\
\hline Daya serap & $61,61 \%$ \\
\hline Ketuntasan & $51,61 \%$ \\
\hline Kategori & Belum tuntas \\
\hline
\end{tabular}


Pada tabel di atas, dapat dilihat proses pembelajaran biologi dengan model (problem based learning) PBL pada siklus I belum tuntas, karena berdasarkan yang diberlakukan di MAN 1 Model Kota Bengkulu, ketuntasan klasikalnya adalah 70\% dengan nilai hasil belajar $\geq 6,4$.

Setelah menganalisa data nilai akhir siswa di siklus I dalam proses pembelajaran yang sudah dilakukan belum mencapai ketuntasan. Tidak tuntasnya proses pembelajaran pada siklus I, dikarenakan dalam proses pembelajaran melalui model Problem based learning belum dilakukan secara maksimal. Sehingga terdapat beberapa kekurangan dalam proses pembelajaran baik dari aktivitas siswa dan maupun aktivitas guru. Oleh karena itu harus ada perbaikkan-perbaikan pada kekurangan dalam proses pembelajaran untuk hasil yang lebih baik pada proses pembelajaran ke siklus selanjutnya.

\section{e. Refleksi siklus 1}

Berdasarkan hasil test dan hasil obsevasi yang telah dicapai, masih terdapat kekurangan. Baik pada aktivitas guru dan siswa pada siklus 1 yaitu:

a. Kekurangan yang terdapat pada guru yaitu: guru masih kurang dalam mengkomunikasikan tujuan pembelajaran dan memotivasi siswa. Guru masih kurang dalam menyampaikan masalah secara jelas.

b. Kekurangan yang terdapat pada siswa yaitu: siswa masih kurang memperhatikan guru dalam menjelaskan tujuan pembelajaran dan belum termotivasi dalam belajar. Siswa kurang memperhatikan dan menjawab masalah autentik yang diberikan.

\subsubsection{Siklus II}

\section{a. Tindakan II}

Pada siklus II dilaksanakan selama dua kali pertemuan dengan menerapkan model Problem Based Learning (PBL). Kompetensi dasar yang diberikan pada siklus II menganalisis jenis-jenis limbah dan daur ulang limbah. Pada tindakan II kegiatan pembelajaran adalah melanjutkan materi dari tindakan I, yaitu menyampaikan Rencana Pelaksanaan Pembelajaran II.

\section{b. Hasil observasi Siklus II}

1) Observasi Aktivitas Guru

Hasil analisa data observasi aktivitas guru pada proses pembelajaran dengan model problem based learning (PBL)pada pencemaran lingkungan dan daur ulang limbah dapat dilihat pada Tabel 4.4.

Tabel 4.4 Hasil Observasi Aktivitas Guru Siklus II

\begin{tabular}{|c|c|c|c|}
\hline \multicolumn{2}{|c|}{ Skor yang didapat } & \multirow{2}{*}{ Rata-rata skor } & \multirow{2}{*}{ Kriteria } \\
\hline Pengamat I & Pengamat II & & Baik \\
\hline 30 & 32 & 31 & . \\
\hline
\end{tabular}


Dari tabel di atas dapat dilihat aktivitas guru selama proses pembelajaran biologi melalui model problem based learing termasuk pada kriteria Baik dengan rata-rata skor 31 .

\section{2) Observasi Aktivitas Siswa}

Hasil analisa data observasi siswa selama mengikuti proses pembelajaran dengan model (Problem Based Learning) PBL disajikan dalam Tabel 4.5.

Tabel 4.5 Hasil Observasi Aktivitas Siswa Siklus II

\begin{tabular}{|c|c|c|c|}
\hline \multicolumn{2}{|c|}{ Skor yang didapat } & \multirow{2}{*}{ Rata-rata skor } & \multirow{2}{*}{ Kriteria } \\
\cline { 1 - 2 } Pengamat I & Pengamat II & 33,5 & Baik \\
\hline 33 & 34 & 3 & \\
\hline
\end{tabular}

Dari tabel di atas dapat dilihat aktivitas siswa selama mengikuti proses pembelajaran biologi melalui model Problem Based Learning termasuk pada kriteria Baik dengan rata-rata skor 33,5. Berdasarkan analisis data dari hasil observasi aktivitas guru dan siswa di siklus II sudah mengalami peningkatan, ini dapat dilihat dari data hasil observasi di siklus I dengan kriteria cukup, dan di siklus II dengan kriteria baik.

\section{c. Nilai Akhir Siswa}

Pada siklus II dilakukan proses pembelajaran biologi pada limbah dan permasalahanya dan daur ulang limbah dengan model problem based learing telah diadakan tes akhir, pada akhir pembelajaran. Untuk mengetahui sejauh mana siswa sudah memahami materi yang baru diperoleh. Nilai akhir ini diguakan untuk penilaian ketuntasan belajar siswa yaitu pada ketuntasan klasikal. berdasarkan jumlah siswa yang mendapat nilai $\geq 6,4$ dapat dihitung nilai ketuntasan belajar klasikal. Dari analisis data dapat diketahui apakah proses pembelajaran sudah tuntas atau belum tuntas.

Dengan menganalisa hasil nilai akhir yang diperoleh siswa, yang mendapat nilai $\geq 6,4$ sebanyak 28 orang siswa. Persentase ketuntasan belajar klasikal adalah $87,5 \%$ dapat dilihat pada Tabel 4.6

Tabel 4.6 Nilai akhir siswa pada siklus II

\begin{tabular}{|c|c|}
\hline Aspek penelitian & Siklus II \\
\hline Hasil belajar & 81,25 \\
\hline Daya serap & $81,25 \%$ \\
\hline Ketuntasan & $87,5 \%$ \\
\hline Kategori & Tuntas \\
\hline
\end{tabular}

Dengan melihat tabel di atas, proses pembelajaran biologi yang dilakukan pada siklus II sudah mencampai ketuntasan belajar klasikal yaitu $87,5 \%$. Ini berdasarkan dengan standar yang telah diberlakukan di MAN 1 Model Kota Bengkulu. 


\section{d. Refleksi}

Selama pelaksanaan pembelajaran siklus II siswa sudah mulai berfikir kritis dan aktif. Pelaksanaan penerapan pembelajaran dengan mengguanakan model problem based learning (PBL) sudah mulai dapat dilaksanakan dengan baik, diantaranya guru sudah memotivasi siswa untuk belajar aktif dan kritis sehingga siswa berani untuk memberikan tanggapan terhadap hasil kerja kelompok lain, dan permasalahan yang diberikan sudah mulai jelas, siswa memperhatikan penjelasan guru dengan serius. Sebagian siswa sudah berani mengeluarkan masalah yang berdasarkan kehidupan sehari-hari.

\subsection{Pembahasan}

Pada penelitian ini, proses pembelajaran yang dilakukan terdiri atas tiga tahap, yaitu pendahuluan, inti, dan penutup. Pada tahap pendahuluan, guru menggali pengetahuan awal siswa melalui pertanyaan. Selanjutnya guru memberikan masalah dalam kehidupan sehari-hari kepada siswa sesuai dengan pokok bahasan Pada kegiatan ini,. Sebagai penutup, guru dan siswa bersama-sama menyimpulkan pembelajaran tersebut.

Hasil tes belajar siswa secara individu yang diperoleh siswa dengan penerapan pembelajaran problem based learning (PBL) menunjukkan peningkatan sebagaimana digambarkan berikut ini :

Pada tes siklus I diperoleh nilai rata-rata hasil belajar siswa sebesar 61,61 sedangkan nilai ketuntasan pada siklus 1 adalah 51,61\%. Hasil belajar pada siklus I belum dikatagorikan tuntas karena 31 siswa yang mengikuti tes terdapat 15 orang siswa yang memiliki nilai lebih kecil dari 64 atau 51,61\% dari jumlah peserta tes. Sedangkan menurut indikator ketuntasan MAN 1 Model Kota Bengkulu, ketuntasan belajar secara klasikal jika hasil tes siswa sebesar $70 \%$ dengan nilai $\geq 64$.

Pada siklus II rata-rata nilai siswa meningkat menjadi 81,25 dengan jumlah ketuntasan siswa juga meningkat menjadi $87,5 \%$. Dengan demikian pada siklus II ini berdasarkan indikator ketuntasan yang diberlakukan tersebut, maka proses dan hasil belajar siswa dapat dikatagorikan tuntas.

Berdasarkan perbandingan hasil tes siklus I dan siklus II, hasil belajar siswa menunjukkan peningkatan yang cukup berarti. Pada siklus 1 rata-rata siswa 61,61 dengan jumlah 15 orang siswa yang tuntas sedangkan pada siklus II rata-rata siswa menjadi 81,25 dengan 28 orang siswa yang tuntas. Hal ini dapat dilihat dari peningkatan nilai rata-rata siswa dan peningkatan jumlah siswa yang memperoleh nilai $\geq 64$. Sehingga dari data diatas dapat disimpulkan dengan mengunakan model Problem Based Learning (PBL) dalam proses belajar mengajar dapat merubah pribadi siswa dari pasif menjadi aktif. Karena siswa dituntut untuk berfikir kritis terhadap masalah nyata dalam kehidupan seharihari sesuai dengan materi pada hari itu.

Dalam proses belajar mengajar ini berjalan dengan baik dikarenakan aktivitas guru maupun aktivitas siswa sudah mengalami peningkatan, ini dapat dilihat dari skor rata-rata dari siklus I ke siklus II pada tebel 4.7 dan tabel 4.8. 
Tabel 4.7 Hasil analisa data observasi aktivitas guru pada siklus I dan II

\begin{tabular}{|c|c|c|c|c|}
\hline Siklus & Pengamat I & Pengamat 2 & Rata-rata & Kriteria \\
\hline I & 25 & 23 & 24 & Cukup \\
\hline II & 34 & 33 & 31 & Baik \\
\hline
\end{tabular}

Tabel 4.8 Hasil analisa data observasi aktivitas siswa pada siklus I dan II

\begin{tabular}{|c|c|c|c|c|}
\hline Siklus & Pengamat I & Pengamat 2 & Rata-rata & keterangan \\
\hline I & 23 & 22 & 22,5 & Cukup \\
\hline II & 33 & 34 & 33,5 & Baik \\
\hline
\end{tabular}

Meningkatnya aktifitas guru dan siswa melalui model problem Based Learning (PBL) dari siklus I ke siklus II karena diadakan perbaikkan-perbaikkan dari aktivitas guru dan siswa yang belum berjalan dengan baik menjadi baik. Ini karena dilakukan perbaikan pada aspek yang masih kurang pada siklus I diperbaiki pada siklus II. Oleh karena itu proses pembelajaran berjalan dengan baik. Pencapaian ini dapat dikatakan bahwa pembelajaran dengan menerapkan model problem based learning (PBL) dapat meningkatkan aktifitas siswa dan guru serta dapat meningkatkan hasil belajar siswa.

Hal ini sesuai dengan hasil penelitian yang relevan : Purwanti, Neni (2005) yang berjudul "Pembelajaran kalor dengan Pendekatan Kontekstual Model PBL (Problem Based Learning) untuk meningkatkan hasil belajar fisika di kelas 2.1 SMPN 4 Bengkulu", menunjukkan bahwa rata - rata nilai siswa pada silkus I 7,15, siklus II 8,1, siklus III 8,4. Sementara itu rata - rata skor aktivitas siswa dalam pembelajaran fisika melalui pendekatan kontekstual model PBL pada siklus I berada pada skor 27,5 (cukup), siklus II pada skor 35 (baik), dan siklus III berada pada skor 39,5 (baik).

\section{KESIMPULAN DAN SARAN}

Pada tes siklus I diperoleh nilai rata-rata hasil belajar siswa sebesar 61,61 sedangkan nilai ketuntasan pada siklus 1 adalah 51,61\%. Hasil belajar pada siklus I belum dikatagorikan tuntas karena 31 siswa yang mengikuti tes terdapat 15 orang siswa yang memiliki nilai lebih kecil dari 64 atau 51,61\% dari jumlah peserta tes. Sedangkan menurut indikator ketuntasan MAN 1 Model Kota Bengkulu, ketuntasan belajar secara klasikal jika hasil tes siswa sebesar $70 \%$ dengan nilai $\geq 64$.

Pada siklus II rata-rata nilai siswa meningkat menjadi 81,25 dengan jumlah ketuntasan siswa juga meningkat menjadi $87,5 \%$. Dengan demikian pada siklus II ini berdasarkan indikator ketuntasan yang diberlakukan tersebut, maka proses dan hasil belajar siswa dapat dikatagorikan tuntas.

Berdasarkan perbandingan hasil tes siklus I dan siklus II, hasil belajar siswa menunjukkan peningkatan yang cukup berarti. Pada siklus 1 rata-rata siswa 61,61 dengan jumlah 15 orang siswa yang tuntas sedangkan pada siklus II rata-rata siswa menjadi 81,25 dengan 28 orang siswa yang tuntas. Hal ini dapat dilihat dari peningkatan nilai rata-rata siswa dan peningkatan jumlah siswa yang memperoleh nilai $\geq 64$. 
Mengunakan model Problem Based Learning (PBL) dalam proses belajar mengajar dapat merubah pribadi siswa dari pasif menjadi aktif. Karena siswa dituntut untuk berfikir kritis terhadap masalah nyata dalam kehidupan sehari-hari sesuai dengan materi pada hari itu. Pencapaian ini dapat dikatakan bahwa pembelajaran dengan menerapkan model problem based learning (PBL) dapat meningkatkan aktifitas siswa dan guru serta dapat meningkatkan hasil belajar siswa.

\section{DAFTAR PUSTAKA}

Amir, M. Taufiq. 2009. Inovasi Pendidikan malalui Problem Based Learning. Jakarta: Kencana.

Arikunto, S. 2002. Prosedur Penelitian Suatu Pendekatan Praktis. Jakarta : Bina Aksara.

Asnimar, dkk. 2008. Model - model Pembelajaran Biologi SMP dan SMA. Palembang: Universitas Sriwijaya.

Daryanto. 2009. Panduan Proses Pembelajaran Kreatif dan Inovatif. Jakarta: Publisher.

Dimyati dan Mudjiono. 2006. Belajar dan Pembelajaran. Jakarta: Rineka Cipta.

Djamarah, Syaiful Bahri dan Zain, Aswan. 2002. Strategi Belajar-Mengajar. Jakarta: Rineka Cipta.

Hanafiah, Nanang dan Suhana, Cucu. 2009. Konsep Strategi Pembelajaran. Bandung: Refika Aditama.

M, Sardiman A. 2008. Interaksi dan Motivasi Belajar Mengajar. Jakarta: Grafindo Persada.

Purwanto. 2005. Tujuan Pendidikan dan Hasil Belajar : Domain Taksonomi. Jakarta : Jurnal Teknnodik No.16/IX/Teknodik/ Juni /2005.

Sakti, Indra dan Connie, 2002. Pedoman Penulisan Skripsi Dan Karya Tulis Ilmiah. Bengkulu: FKIP UNIB.

Sudarman. "Problem Based Learning : Suatu Model Pembelajaran untuk Mengembangkan dan Meningkatkan Kemampuan Memecahkan Masalah." Jurnal Pendidikan Inovatif, Vol. 2 No. 2 Maret. 2007: 69.

Trianto. 2007. Model - model Pembelajaran inovatif berorientasi Konstruktivistik. Jakarta: Prestasi Pustaka. 